\title{
Empathy Levels of University Students Who Do and Not Do Sports
}

\author{
Tülin Atan \\ Faculty of Yasar Dogu Sports Sciences, University of Ondokuz May1s, Turkey
}

Copyright $\bigcirc 2017$ by authors, all rights reserved. Authors agree that this article remains permanently open access under the terms of the Creative Commons Attribution License 4.0 International License

\begin{abstract}
The objective of this study was to compare the empathy levels of university students who do sports and who don't do sports in terms of different variables. For this purpose, 200 Sports Faculty students who do sports at least four days a week for two hours and 200 students from other faculties who don't do sports participated in the study. In the study, Empathic Tendency Scale developed by Dokmen was used as data collection tool. The effects of age, gender, residence place of family, who the students live with and having a social circle on empathy were examined. When the empathy scores of students who do and not do sports were examined, no statistically significant difference was found between the two groups ( $p>0.05$ ). When the empathy scores were examined in terms of gender, empathy scores of women were found to be statistically higher than those of men $(p<0.05)$. When the students' empathy scores were compared in terms of their answers to the question "Who are you living with?", it was found that the students who are living with their families had higher empathy scores than those who are living with their friends $(\mathrm{p}<0.05)$. As a conclusion, it was found that doing sports did not have an influence on empathy levels and women were more emphatic than men. In addition, it was found that the students who lived with their families and those who had a social circle were found to have higher empathic tendency levels.
\end{abstract}

Keywords Empathy, Sport, Gender

\section{Introduction}

Empathy is a person's putting himself/herself in another's place in terms of feelings, thoughts and behaviors and being able to understand and respect that person's point of view, and act together with that person [1]. At the same time, empathy is a person's understanding another person's feelings, thoughts, attitudes and experiences by putting himself/herself in that person's place [2]. Being empathic means reading other people emotionally [3].

In sports environment and especially during sports competitions, it is a reasonable approach that players' empathic characteristics will have an influence on success. Especially in team sports, a player's use of empathic skills while communicating with team mates, trainers and opponent team's players can be an important factor in the team's success since it helps the player to guess how they will act and also helps to build a team spirit [4]. Athletes, referees and spectators, who are the elements of sportive environment, can sometimes show aggressive attitudes and behaviors caused by the excitement and stress of competition and competition environment. These negative attitudes can sometimes cause events that led up to aggressiveness and violence. The concept of empathy becomes more important to be able to eliminate such negative behaviors especially in sportive environments [5].Despite the potential of sports in increasing the skill of social point of view, it has also been found that competition prevents taking role. Being empathic with the opponent can contradict with the "aim of success" and being emphatic with team mates can damage focusing on personal performance. In addition, some trainers do not want their athletes to worry about their opponents on purpose [6].

In empathy exercises in physical training lesson, emotional aspects such as thinking by putting oneself into someone's place and trying to feel that person's feelings are emphasized. The real purpose is to understand the other better and to develop a permanent and positive understanding for the other. Understanding is eliminating bias, preventing aggression and developing social attitudes [7].

This study examines the empathy levels of university students who do sports and those who don't do sports. In addition, the effects of age, gender, the place students live, individuals' thoughts about their physical characteristics and having a social circle on empathy were examined.

\section{Materials and Methods}

\subsection{Study Group}

Data were collected from a sample of 400 participants. 
200 of them were Sports Faculty students, who do sports at least four days a week for two hours. 200 of them were not Sports Faculty but other faculty students who don't do sports. They were instructed that the survey was being conducted by a university-affiliated researcher and there was no monetary incentive for participating. Participants were required to be over the age of 18 , and be university students. The average age of the Sports Faculty participants was $21.13(\mathrm{SD}=1.94)$ years and the other Faculty students was $21.46(\mathrm{SD}=1.55)$ years.

Demographic data questionnaire and Emphatic Tendency Scale were used to collect data. The questionnaire used in this study consisted of 6 items. Items focused on demographic details including faculty, age, gender, residence place of students' family, who the students live with, students' thoughts about their physical characteristics and whether the students have a social circle.

\subsection{The Empathic Tendency Scale}

The objective of Empathic Tendency Scale developed by Dokmen [8] is to measure individuals' potentials of developing empathy in daily life. The scale which consists of 20 items is a 5-likert type grading scale. Half of the items were written with a negative meaning to balance individuals' tendency to say "yes". Individuals read the items and decide on how valid the items are for them and to mark on a grading that ranges from "completely relevant" to "completely irrelevant". Individuals state how much they agree with the item by marking one of the values that range from 1 to 5 next to each item.

The numbers individuals mark make up the scores of that item and negative items are scored inversely. In positive items, the number is scored directly, while negative items are scored inversely. High scores show high empathic tendency, while low scores show low empathic tendency.

The Empathic Tendency Scale, was applied by Dokmen [8] to a group of 70 students twice with three weeks interval. The reliability of the scale is 0.82 obtained from this application. Between the scores of the subjects with single and double scales, the scale was found to have a half-split reliability of 0.86

\subsection{Statistical Analysis}

The SPSS 19 package software was used for the statistical analyses of data. Kolmogorov-Smirnov test was used to find out whether the data were normally distributed. Independent Samples $t$ test and One way ANOVA were used for statistical analysis and Tukey test was used for paired comparisons. Mann Whitney-U test was used when data sets were not normally distributed.

\section{Results}

Table 1. Analysis of empathy scores in terms of different variables

\begin{tabular}{|c|c|c|c|c|c|c|}
\hline \multicolumn{2}{|l|}{ Variables } & $\mathrm{n}$ & Mean & $\begin{array}{c}\text { Std. } \\
\text { Deviation }\end{array}$ & $\mathrm{F}$ & $\mathrm{p}$ \\
\hline \multirow{2}{*}{ Department } & Sport & 200 & 67.00 & 10.40 & \multirow{2}{*}{0.633} & \multirow{2}{*}{0.532} \\
\hline & Other & 200 & 67.89 & 9.71 & & \\
\hline \multirow{2}{*}{ Age } & 20 and younger & 215 & 67.68 & 9.39 & \multirow{2}{*}{0.978} & \multirow{2}{*}{0.693} \\
\hline & 21and older & 185 & 67.11 & 10.92 & & \\
\hline \multirow{2}{*}{ Gender } & Male & 197 & 64.02 & 11.04 & \multirow{2}{*}{3.612} & \multirow{2}{*}{$0.035^{*}$} \\
\hline & Female & 203 & 69.79 & 8.89 & & \\
\hline \multirow{3}{*}{$\begin{array}{l}\text { Residence place } \\
\text { of family }\end{array}$} & Village & 55 & 64.18 & 15.24 & \multirow{3}{*}{2.783} & \multirow{3}{*}{0.064} \\
\hline & Town & 117 & 67.12 & 9.84 & & \\
\hline & City & 228 & 70.38 & 7.23 & & \\
\hline \multirow{3}{*}{$\begin{array}{l}\text { Who are you } \\
\text { living with }\end{array}$} & Family (1) & 183 & 69.26 & 8.87 & \multirow{3}{*}{3.521} & \multirow{3}{*}{$\begin{array}{c}0.032 * \\
1>3\end{array}$} \\
\hline & Alone (2) & 61 & 66.63 & 9.81 & & \\
\hline & Friends (3) & 156 & 65.28 & 11.20 & & \\
\hline
\end{tabular}

$*_{\mathrm{p}}<0.05, * * \mathrm{p}<0.01$

Table 2. Analysis of empathy scores in terms of having a social circle

\begin{tabular}{|c|c|c|c|c|c|c|c|c|c|}
\hline \multicolumn{2}{|c|}{ Variables } & $\mathrm{n}$ & Mean & $\begin{array}{c}\text { Std. } \\
\text { Deviation }\end{array}$ & Median & Min & Max & $\mathrm{z}$ & $\mathrm{p}$ \\
\hline \multirow{2}{*}{$\begin{array}{c}\text { Do you have a } \\
\text { social circle? }\end{array}$} & Yes & 258 & 67.84 & 9.67 & 68.00 & 39.00 & 89.00 & \multirow{2}{*}{-1.975} & \multirow{2}{*}{$0.048^{*}$} \\
\cline { 2 - 23 } & No & 42 & 59.90 & 14.20 & 63.50 & 30.00 & 83.00 & \\
\hline
\end{tabular}


Table 1 shows the empathy scores of students studying at the faculty of sports sciences and the scores of students who were not studying at the faculty of sports sciences and no statistically significant difference was found between the two groups $(\mathrm{p}>0.05)$.

Empathy scores of students older and younger than 20, were compared and no statistically significant difference was found ( $\mathrm{p}>0.05)$.

When the empathy scores were analyzed in terms of gender, women's empathy scores were found to be statistically higher than those of men's $(\mathrm{p}<0.05)$.

No statistical difference was found between the empathy levels between living in villages, towns or cities of families $(\mathrm{p}>0.05)$.

When the students' empathy scores were compared in terms of the answers to the question "who are you living with?", it was found that students who live with their families have higher empathy scores when compared with students who live with their friends $(\mathrm{p}<0.05)$.

Table 2 shows the students' empathy scores in terms of the answers given to the question "do you have a social circle?". It was found that the students who have social circle had higher empathy scores when compared with those who do not have social circle $(\mathrm{p}<0.05)$.

\section{Discussion}

This study examined the empathy levels of university students in terms of different variables. In our study, when the empathy scores of students who do sports were compared with the scores of students who don't do sports, it was found that students of both groups had similar empathy tendency levels. That is, it was found that doing sports don't have an influence on empathy. Solak's [9] study supports the findings of our study. In his study, emphatic tendency score do not change in terms of the variable of doing sports. Akcakoyun et al. [10] aimed to compare the empathic tendency level of the athletes who do team sports and martial arts and they found no significant difference in empathy levels between groups considering sports type.

In this study, no difference was found between the empathy scores of students younger than 20 and older than 21. Studies which support the findings of our study were found. In the previous study, no difference was found between the emphatic skill scores of university students who were between the ages of 17 and 19,20 and 22 and older than 23 [11]. In a study which examined the empathic tendency levels of prospective teachers of physical education, it was found that empathic tendency scores did not differ in terms of age [12]. Conversely, our results are different from the results of previous study which reported empathy was affected by age. Kilic [13] examined the empathic skill levels of preschool teachers and found that empathic skill level decreased with the increase in age. Contrary to this study which state that age influences empathy level, it was found in our study that age do not influence empathy level. The reason for this can be the fact that the age range of the sample groups between the studies.

When the literature is examined, significant difference can be seen between the empathy levels of genders in general. The results of our study were also in line with the literature. Women were found to have higher empathy scores than men. This finding coincides with the results of previous studies [5, 14-18]. Bozkurt [14] examined the emphatic tendency levels of Hacettepe University students who had different genders, faculties and adaptation levels. He found that female students had higher empathy tendency levels than those of male students. Arslanoglu [18] stated that female students studying at the school of physical education and sports had higher empathic tendency levels than male students. When the empathy levels of team sports athletes of different genders were examined in Dorak and Vurgun's [16] study, empathy levels of female students were found to be higher than those of male students. According to the results of a study conducted by Alper [17] to find out gender differences, it was found that although women had higher emotional empathy levels, no significant gender differences were found in cognitive empathy measurements. In a study conducted on middle school students, empathic tendency scores of female students were found to be higher than those of male students[5]. Results of previous studies show us that women can develop empathy more than men. It can be said that athletes of a female team are more understanding and sharing than male athletes and they can solve problems more easily. The results of studies are in parallel with our results.

However, some of the earlier studies have stated that gender does not have an influence on the level of empathy. In a study which examined the empathic tendencies and problem solving skills of prospective teachers in terms of different variables, empathic skills were not found to differ in terms of the variable of gender [19]. Koksal [20] found that gender did not cause a significant difference on the empathic skill scores of adolescents. In a study which examined the empathic tendency levels of prospective physical education and sports teachers, empathic tendency scores were not found to differ in terms of gender [12].

In our study, empathy levels of students whose families live in villages, towns and cities were not found to differ. When empathy scores were compared in terms of the answers given to the question "who are you living with?", students who live with their families were found to have higher empathy scores than those who live with friends.

In our study, students' empathy scores were compared in terms of the answer given to the question "do you have a social circle?" students who have social circle were found to have higher empathy scores when compared with the students who do not have social circle. No such difference was found in Kumbaroglu's study [4]. The reason why there were different results in Kumbaroglu's study and our study may be the students in Kumbaroglu's study were middle school students. 


\section{Conclusions}

Doing sport did not have an influence on empathy level and women were found to be more emphatic when compared with men. In addition, the students who live with their families and those who have social circle were found to have higher emphatic tendency levels.

\section{REFERENCES}

[1] N. Tarhan. Toplum Psikolojisi: Sosyal Sizofreniden Toplumsal Empatiye. Timas Publication 1.Press, Istanbul. 2010.

[2] K. Altınbas, S. Guloksuz, S. Ozcetinkaya, E.T. Oral empatinin biyolojik yönleri. Psikiyatride güncel yaklasimlar. Vol.24, No.6, 575-588, 2010.

[3] A. Yuksel. The relationship between empathy, self-concept and family functioning among 5th grade elementary. Pamukkale University Journal of Education Faculty, Vol.1, No.25, 153-165, 2009.

[4] A.B. Kumbaroglu. Comparison of empathic tendency levels and self-esteem levels of secondary school students who are doing exercise and who are not, according to various socio-demographic characteristics. Unpublished $\mathrm{PhD}$ thesis, Institute of Health Sciences, Ankara: University of Gazi, 2013.

[5] F.F. Colakoglu, N. Solak. Analysis and examination of aggression levels and empathetic tendency levels of secondary school students according to the type of school and gender (case of Corum province). International Journal of Social Science, Vol.26: 57-66, 2014.

[6] G.S. Balcikanli, I. Yildiran. Sportsperson ship orientation and empathic dispositions of professional soccer players. Spormetre Journal of Physical Education and Sports Sciences, Vol.IX, No.2, 49-56, 2011.

[7] A. Luther, A. Hotz. Fairness im sport-lernen für's leben?.Leibesübungen-Leibeserziehung, Vol.48, No.5, 4-8, 2004.

[8] U. Dokmen. Empatinin yeni bir modele dayanılarak ölçülmesi ve psikodrama ile geliştirilmesi. Ankara University, Journal of Faculty of Educational Sciences, Vol.21, No.1, 155-190, 1988.

[9] N. Solak. Examination of the relationship between the levels of aggression and levels of the emphatic tendencies of secondary education students who do sports and those who do not do sports (the Corum case). Unpublished $\mathrm{PhD}$ thesis,
Institute of Education Sciences, Ankara: University of Gazi, 2011.

[10] F. Akcakoyun, E. Caliskan, H. Karli.The comparison of empathy levels of martial artists and team sportsmen. Turkish Kick Boxing Federation Journal of Sport Science, Vol.3, No.2, 2010.

[11] N.H. Korkmaz, E. Sahin, M. Kahraman, F. Ozturk. Comparison on the empathic abilities of the students at U.U. Physical Education and Sport Department according to their ages. Journal of Uludag University Faculty of Education, Vol.XVII, No.1, 95-103, 2003.

[12] G. Y1lmaz, Y. Akyel. (2008). Examination of empatic tendency levels of physical education candidates teacher in terms of different variables. Journal of Kirsehir Education Faculty (KEFAD), Vol.9, No.3, 27-33, 2008.

[13] S. K1lic.Studying the emphatic skills of pre-school teachers in Istanbul in relation to some variables. Unpublished Master's thesis, Institute of Education Sciences, İstanbul: University of Marmara, 2005.

[14] A. Bozkurt. The empathic tendency levels of the Hacettepe University student from different sexes, faculties and adjustment levels. Unpublished master's thesis, Institute of Social Sciences, Ankara: University of Hacettepe, 1997.

[15] E. Duru. Öğretmen adaylarında empatik eğilim düzeyinin bazı psikososyal değişkenler açısından incelenmesi. Pamukkale University Journal of Education Faculty, Vol.2, No.12, 21-35, 2002.

[16] F. Dorak, N. Vurgun. The relation of empathy and team cohesion in terms of team sports. University of Ankara Spormetre Journal of Physical Education and Sports Sciences, Vol.IV, No.2, 73-77, 2006.

[17] D. Alper. The comparison of emotional intelligencecommunication and empathy skills levels of psychological counselors and primary school teachers. Unpublished Master's thesis, Institute of Education Sciences, İzmir: University of Dokuz Eylul, 2007.

[18] C. Arslanoglu. Evaluation of the empathic tendency levels and aggression relationship of physical education and sports students from different departments. Unpublished $P h D$ thesis, Institute of Education Sciences, Ankara: University of Gazi, 2012.

[19] Z.K. Genc, T. Kalafat. Prospective teachers' problem solving skills and emphatic skills. The Journal of Theoretical Educational Science, Vol.3, No.2, 135-147, 2010.

[20] A. Koksal. Müzik eğitimi alma, cinsiyet ve sınıf düzeyi değişkenlerine göre ergenlerin empatik becerilerinin ve uyum düzeylerinin incelenmesi. Hacettepe University Journal of Education, Vol.18, 99-107, 2000. 